Article

\title{
Integrated Application of Remote Sensing and GIS in Crop Information System-A Case Study on Aman Rice Production Forecasting Using MODIS-NDVI in Bangladesh
}

\author{
B. M. Refat Faisal *, Hafizur Rahman, Nur Hossain Sharifee, Nasrin Sultana, \\ Mohammad Imrul Islam, S. M. Ahsan Habib and Tofayel Ahammad
}

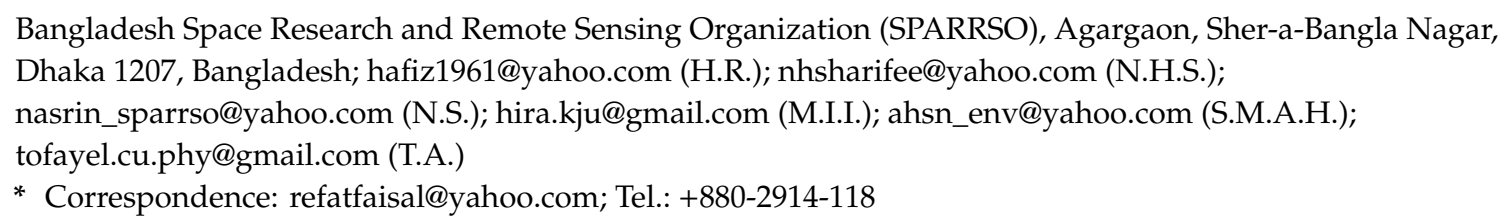

* Correspondence: refatfaisal@yahoo.com; Tel.: +880-2914-118

Received: 2 April 2020; Accepted: 30 April 2020; Published: 12 May 2020

\begin{abstract}
This research work studies the integrated application of satellite Remote Sensing (RS) and Geographic Information System (GIS) for the monitoring and forecasting of rice crop (Aman) production in Bangladesh. Normalized Difference Vegetation Index (NDVI) images of Terra MODIS products MOD13A1 (h25v06 and h26v06) with $500 \mathrm{~m}$ spatial resolution, composed using Maximum Value Composite (MVC) techniques, were used to cover Bangladesh for the period of 2011-2017. Country scale NDVI (district-wise summation) was calculated pixel-by-pixel to draw a regression curve while using Bangladesh Bureau of Statistics (BBS) estimations of Aman production for the months of September-November. The regression study of district-wise pixel-based summation of MODIS-NDVI and ground-based BBS-estimated Aman production shows a strong correlation $\left(\mathrm{R}^{2}=0.54-0.78\right)$; for the months of September and October, most of the regression coefficient indicates significant correlation due to maximum photosynthetic activities. Therefore, based on the highest regression coefficient value of September and October, Aman Crop Production (ACP) models were developed and the ACP Model-2 was exploited (from the derived set of coefficient values) to acquire year-wise rice production for all the years (2011-2017). The simulated ACP Model-2 demonstrates good agreement between the estimated and predicted yearly Aman rice production for the 2011-2017 time period with Mean Bias Error $(\mathrm{MBE})=(-9435$ to 23,156$)$ M.Ton; Root Mean Square Error $($ RMSE $)=253-4426$ M.Ton; Model Efficiency $(\mathrm{ME})=(0.89-0.93) ;$ and, Correlation Coefficients = (0.72-0.94). Hence, the MODIS-NDVI-based regression model seems to be effective for Aman crop production forecasting in the context of food security issues in Bangladesh. The applied system is simple, rationally accurate, and fit for the generation of nationwide crop statistics.
\end{abstract}

Keywords: RS_GIS; Aman crop; MODIS-NDVI products; ground-based estimates; regression model; simulation; forecasting

\section{Introduction}

Rice production is of essential importance in Bangladesh and in the context of economy and food security issues [1], where the grain solely occupies $76.7 \%$ of total area under cultivation [2]. Aus, Aman, and Boro are the three major types of rice cultivated in Bangladesh; where Boro or winter rice is grown from January to June under irrigated conditions, while the Transplanted Aman (T. Aman or monsoon rice) is grown from July to December, mostly under rain-fed conditions [3]. Presently, 
in Bangladesh, Aman rice accounts for about $50 \%$ of the total rice production in the country [4]; nevertheless, the yield gaps between the Boro and Aman seasons are about 0.9 tons ha $^{-1}$ and 1.3 tons $\mathrm{ha}^{-1}$ due to biotic and socio-economic constraints. Monsoon rains are very important for the Aman crop, which is harvested in November/December. However, Aman rice requires a special habitat of prolonged flooding. A maximum amount of Aman is transplanted between the end of June to mid-August, although planting can occur as late as the last week of September and harvested in November/December [5]. In view of the above, early assessment of Aman crop production in the context of Bangladesh is very important due to food security issues.

Crop production assessment in Bangladesh is done by considering the crop acreage estimates and corresponding crop yield estimates, which are often subjective, costly, and prone to large errors, thus leading to poor crop assessment [6]. Besides, the collected information might become available too late for appropriate action to be taken by the decision-makers or planners in the country. On the contrary, remote sensing can help obtain surface information macroscopically, periodically, and economically; and, has many advantages in agricultural monitoring-great success has been achieved in the recent past [7-10]. In this context, Normalized Difference Vegetation Index (NDVI) is a key signifying factor for vegetative growth conditions and degree of vegetative cover study [11]. Ref. [12] It is to be noted that, if an area is covered by vegetation, then the NDVI value of that area is a positive number, and it increases along with an increase in vegetative cover. A few studies have attempted to estimate rice yield using high-resolution remote sensing data (such as Quickbird; $0.65 \mathrm{~m}$, WorldView; $0.31 \mathrm{~m}$ and IKONOS; NIR $3.2 \mathrm{~m}$, PAN $0.82 \mathrm{~m}$ ) in the past two decades [13]; however, their approach has encountered problems with swath width and high costs [14,15]. Similarly, the use of Landsat imagery has encountered problems with obtaining cloud-free images due to temporal resolution, which makes it impossible to obtain phenology information during the relevant crop period.

However, MODIS constellations have been used in retrieving agricultural crop information and they are mostly used due to their larger regional scale, smaller dataset, and faster revisiting time [16,17]. Moreover, the dynamics of MODIS-derived NDVI products is representative of crop growth and biomass changes that are closely related to crop yield and it has a direct relationship with Leaf Area Index (LAI), biomass, and vegetation cover [18-20]. The suitability of using MODIS-derived NDVI data for crop yield estimation prediction, crop production, and monitoring has been recommended by several studies [21-24]. Therefore, the MODIS-derived NDVI product is used in this study. The present study focuses on NDVI, because it is widely used in phenological works [25-27] and it is known to be more sensitive to small increases in the amount of photosynthetic vegetation [28,29]. In view of the above, the objectives of this study are to forecast seasonal crop (Aman) production estimates based on the developed methodology for potential use in tackling the country's food security issues.

\section{Materials and Methods}

\subsection{Study Area}

The study area is located between $20^{\circ} 34^{\prime}$ to $26^{\circ} 38^{\prime}$ North latitude and $88^{\circ} 01^{\prime}$ to $92^{\circ} 42^{\prime}$ East longitude, except for the southeastern three hilly districts (Rangamati, Khagrachari, and Bandarban) of Bangladesh. Figure 1 shows the NDVI distribution in the study area. The three hilly districts mentioned above are not considered in this study, because surface reflectance from the hilly terrain might be influenced by adjacent areas, as has been stated in several studies [30-32]. In Bangladesh, the mean annual rainfall is about $2300 \mathrm{~mm}$; however, annual rainfall ranges from $1200 \mathrm{~mm}$ in the extreme west to over $5000 \mathrm{~mm}$ in the east and north-east [33]. Regional variability in agricultural production pattern and a diverse landscape in the country has resulted in temporally and spatially fragmented rice production areas $[34,35]$. Among the three rice-producing seasons, the primary production season generally lasts from July to November, depending on the region; the dry (Boro) irrigated rice is generally planted in December or January and harvested in March or April; and, the early summer season (Aus) is a short rice season, which precedes Aman in a few areas [36]. The geomorphological characteristics 
of Bangladesh imply that the Aman crop has to experience dry and wet climatic conditions due to a longer growing season. With respect to the Aman crop, early rainfall is negatively correlated, whereas monsoon rainfall is important for the maturity of rice grains.

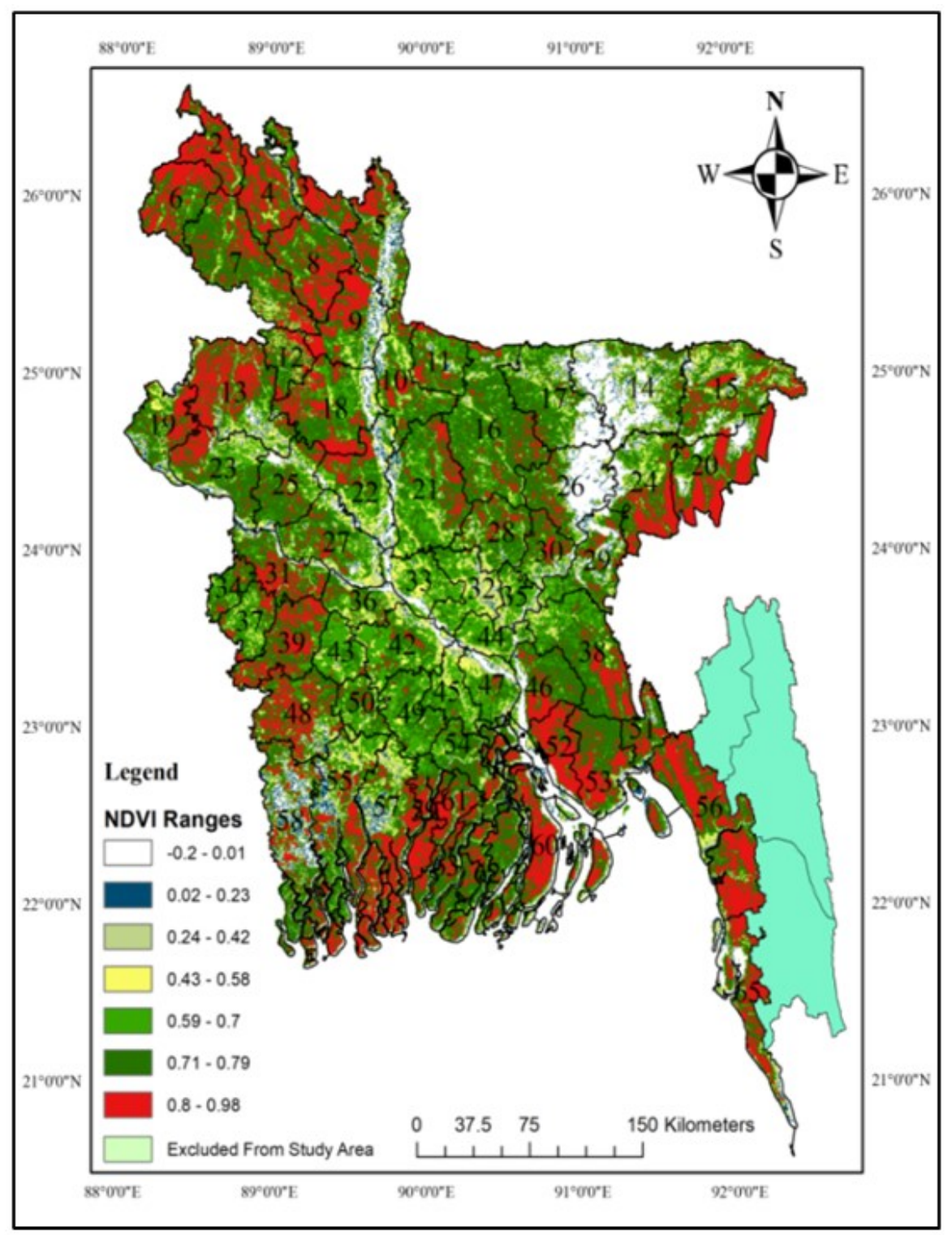

Figure 1. Normalized Difference Vegetation Index (NDVI) distribution in Bangladesh derived from MODIS NDVI imageries.

\subsection{Phenology of Aman Crop in Bangladesh}

The Aman rice crop phenology is divided into three distinct phases: (1) vegetative phase, (2) reproductive phase, and (3) ripening phase. The vegetative phase starts out by germination and ends with the initiation of a panicle (Table 1). The vegetative phase lasts from 55 to 85 days, depending on the Aman crop varieties. The Aman crop yield largely depends on the reproductive phase that persists from panicle initiation to flowering. The ripening phase lasts from the flowering of the plants to the maturity of grain. The rainy days with low temperatures may lengthen the ripening phase while sunny and warm days may shorten it. Usually, the most of the Aman crop varieties take 30 to 35 days for the completion of their reproductive and ripening phase each [37]. The phenological changes of the crops life cycle are demonstrated in Figure 2 using MODIS derived NDVI distribution of four different times. 
Table 1. Phenological stages of Aman crop.

\begin{tabular}{cccc}
\hline \multicolumn{4}{c}{ Phases (Days) } \\
\hline Vegetative Phase & Reproductive Phase & Ripening Phase & Total \\
\hline 55-85 days & $30-35$ days & $30-35$ days & $115-155$ days \\
\hline \multicolumn{4}{c}{ Source: [37]. }
\end{tabular}

MODIS NDVI Distribution on 29 Sep 2012

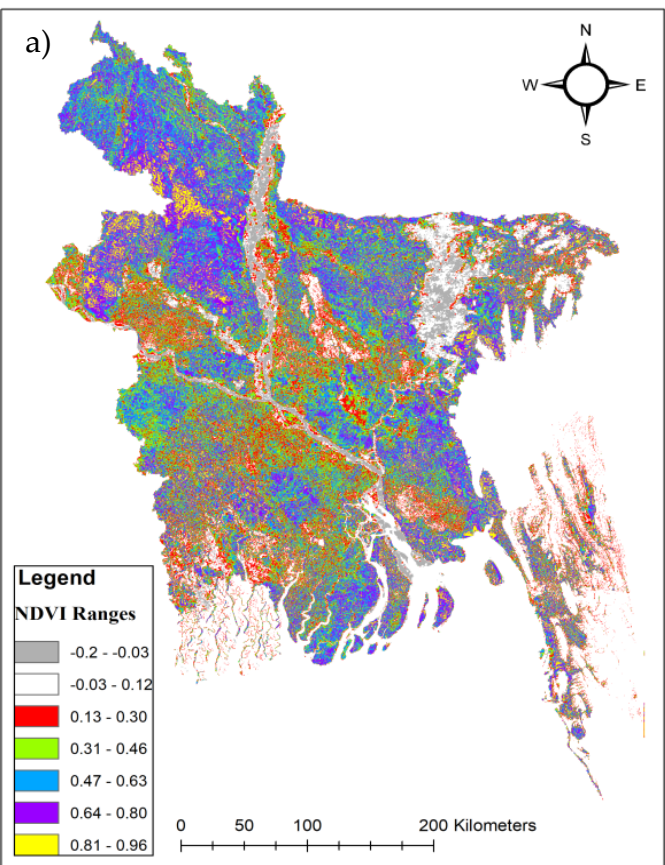

MODIS NDVI Distribution on 31 Oct 2012

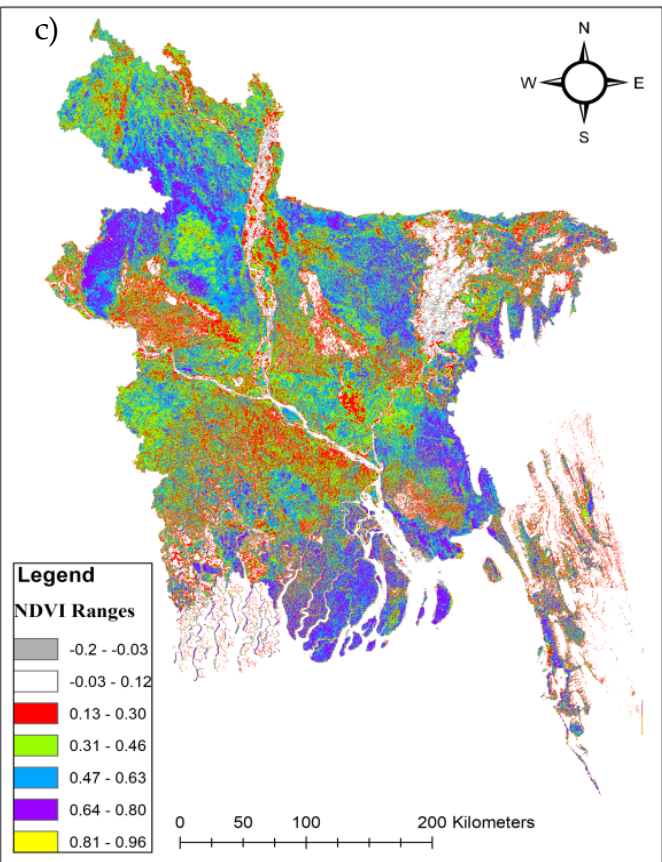

MODIS NDVI Distribution on 15 Oct 2012

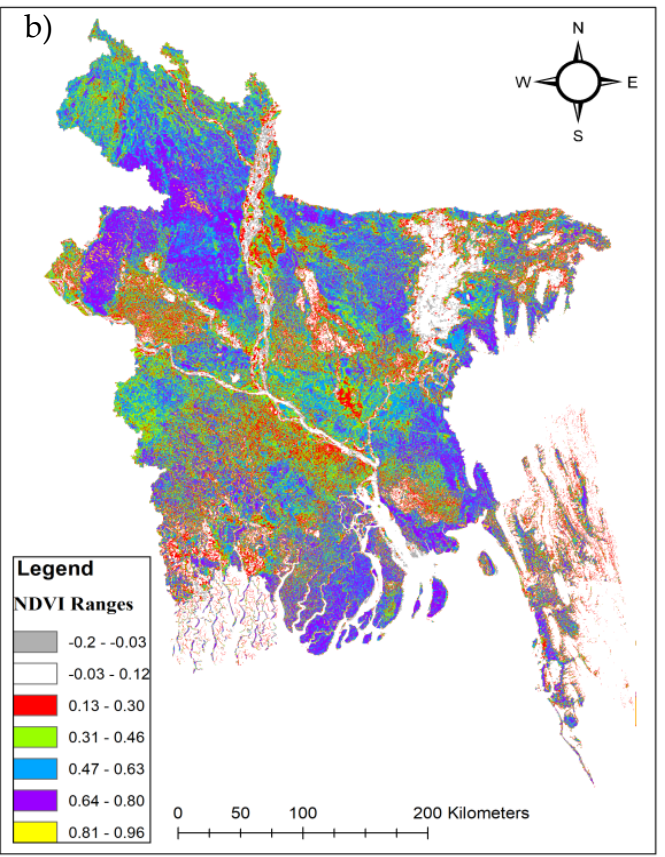

MODIS NDVI Distribution on 16 Nov 2012

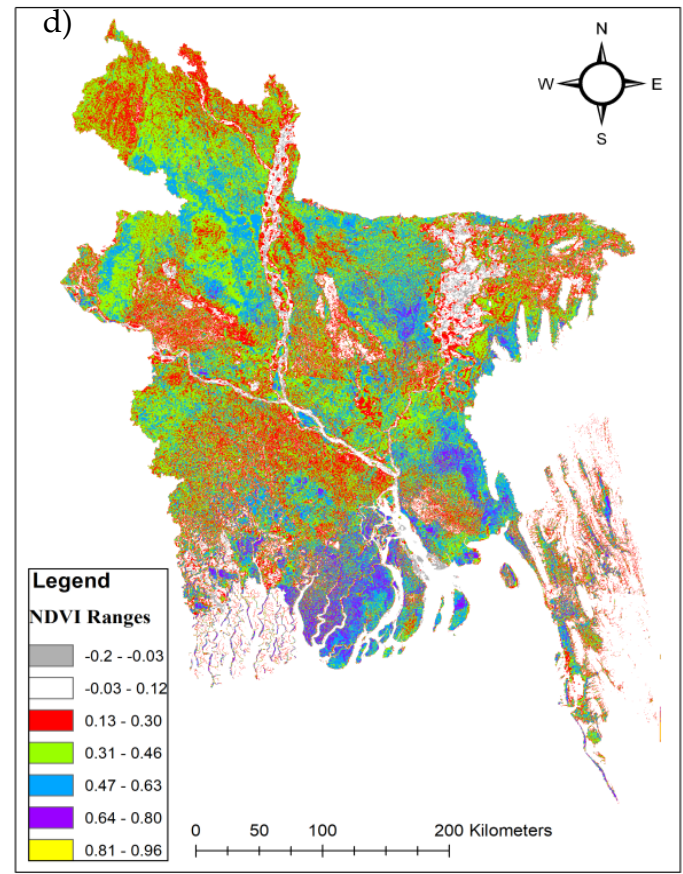

Figure 2. (a-d): Phenological changes of crops based on MODIS NDVI distribution at different dates in a year (2012). 


\subsection{Geospatial Data Used}

The two MOD13A1 scenes (MOD13A1: h25v06 and h26v06) have been accessed from the website of the US National Aeronautical Space Agency (NASA) Earth Observing System (EOS) in Hierarchical Data Format (HDF-EOS) to serve the purpose of the present study [38]. The applicability of MODIS VI products (MOD13A1) for the crop production forecasting in Bangladesh has already been proven by [24]. Therefore, the Terra MODIS 16-day Maximum Value Composite (MVC) NDVI image products (MOD13A1) of $500 \mathrm{~m}$ resolution have been utilized in the present study in order to gather Aman crop information in the context of Bangladesh. The pixel-by-pixel cloud-free quality images can be obtained from MVC NDVI images, which can effectively identify the major changes in crops phenology. Accordingly, the growth of the Aman crops at different stages of its life cycle can be monitored by MVC NDVI images. The utility of MVC products for generating Boro crop information in Bangladesh has been tested and well documented in [24]. On the basis of the phenology of the Aman crop lifecycle in Bangladesh, the study period is accounted from September to November of 2011 to 2017. Eventually, each image of MODIS MVC products corresponding to each month as obtained is based on the selection of the best pixel value from a total of 16 images of 16 consecutive dates of the same pixel. Tables 2 and A1 summarize the detailed specifications of used MODIS NDVI products and satellite image acquisition date, respectively.

Table 2. MODIS NDVI products (MOD13A1) description.

\begin{tabular}{cccccc}
\hline Data Source & Data Description & Data Type & Pixel Size & Composite Technique & File Format \\
\hline Terra MODIS & $500 \mathrm{~m} 16$ days NDVI & 16-bit signed integer & $500 \mathrm{~m}$ & MVC (Maximum Value Composite) & HDF-EOS \\
\hline \multicolumn{6}{c}{ Source: [38]. }
\end{tabular}

The ground-based estimated Aman rice crop production statistics from 2011-2017 have been collected from the Bangladesh Bureau of Statistics (BBS). For yield/production estimation information, BBS follows the Food and Agriculture Organization (FAO) guided conventional methods (direct observation and measurement) and collects data from 10,348 numbers of clusters, where each cluster averaging five acres of land as a sample frame. The detailed procedure of yield/production estimation information of BBS has been described in [24] and in [39].

\subsection{Methodological Framework}

Figure 3 illustrates a methodological framework for this study. After acquisition of satellite data multiple steps of pre-processing likely (a) conversion of Hierarchical Data Format (HDF) dataset into image compatible format through MODIS Conversion Tool-kit (MCTK) and ENVI software; (b) digital mosaicking of converted images (MOD13A1: h25v06 and h26v06); (c) re-projection of the NDVI images into Transverse Mercator; and, (d) necessary geometric correction have been performed in order to develop rice production forecasting methods.

After the necessary pre-processing of satellite imageries, the country scale vegetation layer has been used to mask out the non-crop vegetation cluster using Erdas Imagine software. The prime objective of using country scale vegetation mask layer is to screen out the part of vegetation that was mostly stable or having unchanged cover for relatively longer time period. The used country scale vegetation mask layer consists of (i) forest features, (ii) homestead vegetation together with (iii) seasonal crops, and (iv) mostly non-vegetated soil areas. These vegetation mask layers have been generated from high-resolution satellite data (RapidEye/Landsat) and they have been utilized to find the district-wise rice pixel only in present study. The regular updating of these vegetation layers every 3-4 years can give satisfactory updated surface features at the country scale. The detailed procedure for preparing this vegetation mask layer has been stated in [24]. The Pixel-wise spatial summation of NDVI values for all of the individual pixels covering each individual district area in the MVC NDVI image provides a single value for each district. Hence, a district-wise pixel-to-pixel addition operation has been carried out to provide NDVI summation of all pixels i.e., $\sum_{i=1}^{n}$ NDVI for each district areas 
based on MODIS NDVI raster layer properties supported by the GIS boundary layer. Here, $\mathrm{n}$ is the total number of data points (pixels) under a district.

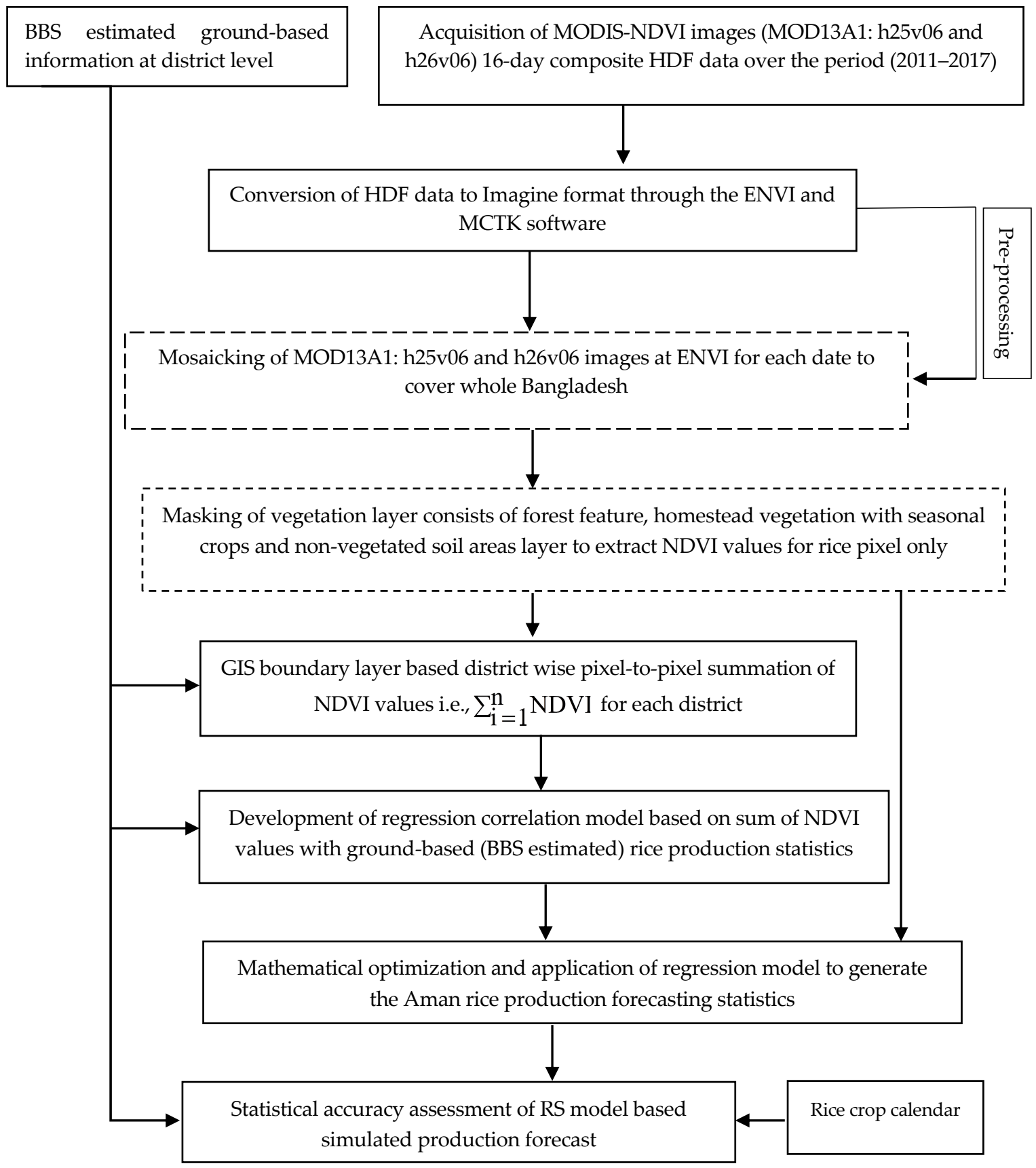

Figure 3. Schematic illustration of remotely sensed Aman rice production forecasting methodology (Note-RS: Remote Sensing; NDVI: Normalized Difference Vegetation Index; BBS: Bangladesh Bureau of Statistics; MCTK: MODIS Conversion Toolkit).

Therefore, the district-specific sum of NDVI values has been extracted from September to late November over the years 2011-2017. Ultimately, the derived summed NDVI is the resultant of all the pixels within each district area and it is assumed to be proportional to the presence of vegetation therein. Hereafter, based on MODIS derive district wise sum of MODIS-NDVI values with ground-based (BBS estimated) Aman rice crop production statistics, the regression analysis has been performed for the period of 2011-2017. Subsequently, based on the highest regression (Monthly Scale) coefficient value, the regression model of October 2012 (ACP Model-2) has been applied to independently 
generate crop production statistics at the country scale (Table A1). After that, the Remote Sensing (RS) model-based simulated results have been compared with ground-based BBS estimated Aman crop production statistics for testing or validating the model, which were not used to retrieve the values of the parameters. After the model simulation, necessary statistical parameters, like (a) Mean Bias Error (MBE); (b) Root Mean Square Error (RMSE); and, (c) Model Efficiency (ME), have been derived for suitability assessment by applying the Equations (1)-(3).

$$
\begin{gathered}
\text { MBE }=\frac{\sum_{i=1}^{n}\left(P_{i}-O_{i}\right)}{n} \\
\text { RMSE }=\sqrt{\frac{\sum_{i=1}^{n}\left(O_{i}-P_{i}\right)^{2}}{n}} \\
M E=\frac{\left[\sum_{i=1}^{n}\left(O_{i}-\bar{O}\right)^{2}-\sum_{i=1}^{n}\left(P_{i}-O_{i}\right)^{2}\right]}{\left[\sum_{i=1}^{n}\left(O_{i}-\bar{O}\right)^{2}\right]}
\end{gathered}
$$

where $n$ is the number of data points, $P_{i}$ is the $i^{\prime}$ th model predicted data point, $O_{i}$ is the $i^{\prime}$ th observed data, and $\overline{\mathrm{O}}$ is the mean of the observed data.

\section{Results}

This section illustrates the research outcomes, limitations, and way forward for future study.

\subsection{Remotely-Sensed Aman Rice Production Model}

The potentiality of regression model derived from remote sensing NDVI and ground-based crop statistics to estimate the crop yield [40-42] and crop production [24,43] under different land management has been notified. Generally, the Aman season in Bangladesh continues from the month of August/September to November/December. Consequently, the maximum NDVI values can be found during peak greenness period of crop life cycle, which is around the month of October. A linear regression model has been developed between the sum of MODIS-NDVI and ground-based (BBS estimated) crop production from September to November of 2011 to 2017 (Table A1). The regression coefficient value ranges from (0.54-0.78) among the individually developed twenty-eight (28) regression coefficients (Table A1). The highest $\left(R^{2}=0.78\right)$ and lowest $\left(R^{2}=0.54\right)$ regression coefficient values have been found for the month of September of 2012 and November of 2015, respectively. Besides, the highest regression coefficient for the month of October $\left(R^{2}=0.76\right)$ has been found in 2012 over the time period 2011-2017, which is also considered as a peak greenness period in context of Bangladesh. Accordingly, the regression coefficient shows the higher regression value for the month of September/October among the entire regression coefficient. Several studies [44-49] depict that the peak greenness period represents the highest NDVI values and it is related to crop production.

The developed regression equation illustrates the distinctive relation between Aman rice crop productions with sum of MODIS-NDVI values, which depicts that the increases of sum of MODIS-NDVI during the peak greenness period are generally related to Aman crop production. Other studies support the observed strong positive relationship between the sum of MODIS derived NDVI and ground-based Aman crop production in the present study [24,50]. In the present study, it is found that the regression coefficient becomes low in late November in all cases (Figure 4), which indicates the harvesting period of Aman crop and results in low NDVI values during this time. Therefore, based on the highest regression coefficient, month-wise regression models have been derived to simulate Aman crop production that is likely for the month of September (ACP Model-1) and October (ACP Model-2). 
(Sep) Aman Crop Production $(\text { ACP })_{(\text {M.Ton })}=0.2596 \times \sigma-21,026 \quad($ ACP Model-1)

$(\mathrm{Oct})$ Aman Crop Production $(\mathrm{ACP})_{(\mathrm{M} . \mathrm{Ton})}=0.2605 \times \sigma-29,779 \quad(\mathrm{ACP}$ Model-2)

where the dependent variable (ACP) is expressed in absolute values (M.Tons) for each district; 0.2596 and 21,026; 0.2605 and 29,779 are the regression coefficients; and, $\sigma$ is the sum of NDVI values for each district.

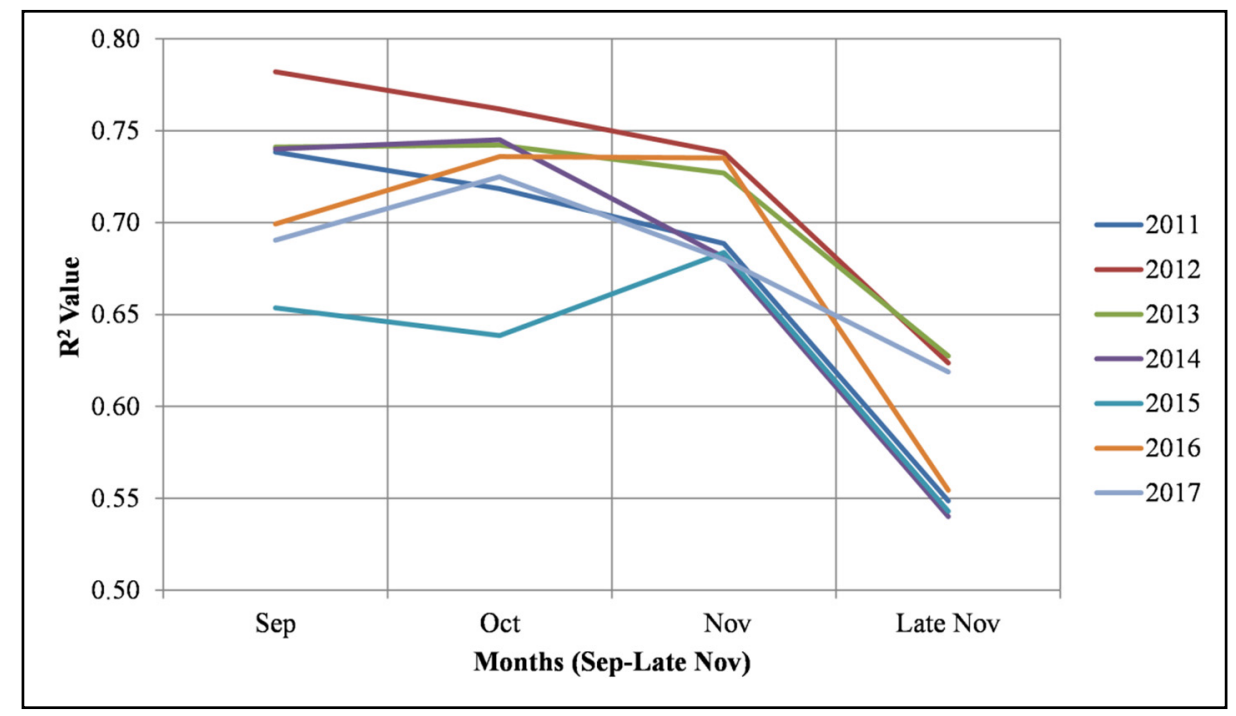

Figure 4. Variations of monthly derived remote sensing regression models (2011-2017).

\subsection{Simulation of Remotely Sensed Rice Production Model}

The derived remote sensing regression models (ACP Model: 1 and 2) have been applied to simulate the Aman crop production for each of the years of 2011 to 2017. The difference between the predicted and estimated production is found to be larger in the ACP Model- 1 as compared to the ACP Model-2. The simulation result of ACP Model-2 might become closer to the estimated production, because high NDVI values indicate enhanced photosynthetic activities towards the peak growth stage of Aman rice crop. However, RS-derived ACP Model-1 can also be used, but ACP Model-2 is more applicable and suitable, as October is the peak greenness month in the context of Bangladesh.

A simulation result of ACP Model-2 has been summarized over the time period of 2011 to 2017 in this section. The coefficient values of the regression model have been derived through mathematical optimization of the model against a single year data of October 2012. Subsequently, using the same set of derived model coefficient values (that of October 2012), data for the other years 2011 to 2017 have been independently generated. For training the model, only one year (2012) has been exploited and the remaining years have been evaluated. Table A2 provides statistics of Aman rice production over the years (2011-2017) according to RS Model-based (ACP Model-2) estimation along with ground-based BBS estimation. The RS Model-based observation versus BBS estimated production statistics (Table A2) shows relatively high correlation $\left(R^{2}=0.72\right.$ to 0.94$)$ for each of the years from 2011 to 2017. The differences between the predicted and official statistics demonstrate the potential of a remotely sensed MODIS-NDVI based Aman rice production estimate at the country scale. Therefore, necessary statistical measures, like MBE, RMSE, and ME, have been employed to analyze the suitability of developed ACP models [51]. Several studies relevant to crop yield forecasting, notably $[24,45,48,52,53]$ have also found good relationship between estimated and predicted rice yield for different countries. 


\subsection{Suitability Assessment of Developed ACP Model}

Based on the relevant study [53], the accuracy assessments of derived Aman crop production forecasting models have been mathematically performed [54], as described in Equations (1)-(3). The regression model based estimated crop statistics from ACP Model-2 has been assessed with statistical parameters MBE and RMSE presented in Figure 5 with a radar chart. Besides, Figure 6 also shows a strong relationship $\left(\mathrm{R}^{2}=0.72\right.$ to 0.94$)$ between predicted and estimated value of Aman crop in Bangladesh for the year 2011 to 2017. The MBE for applied Aman forecasting model ranges from $(-10,353$ to 11,691$) \mathrm{M}$. Ton, which reveals that the applied model underestimates the Aman production for the year 2011, 2014, 2015, and 2017, whereas overestimates for the year 2012, 2013, and 2016 as the positive MBE gives the average amount of overestimation in calculated value and vice versa [54]. The RMSE value for the applied model ranges from (842-5067) M. Ton, which is a positive value, and also the use of RMSE in model validation has been appreciated by $[53,55]$. Model Efficiency (ME) is also used to assess the potentiality of model and, here, the ME ranges from (0.90-0.92) for the applied Aman crop forecasting model. The relevant literature clarifies, ME of 1 is a perfect match of modeled data to forecasted data whereas closer value of ME to 1 demonstrates its better accuracy [56]. Hence, the present ME over the period of (2011-2017) shows potentiality for using this model for Aman crop production forecasting at the country scale. Therefore, the MBE, RMSE, and ME values in this study indicate close prediction results for Aman crop forecasting estimates during 2011-2017 for Bangladesh (Table A2). The forecasted and estimated Aman production shows strong relationship, but this model-based forecasting methodology does not consider the unexpected weather condition $[16,56]$.

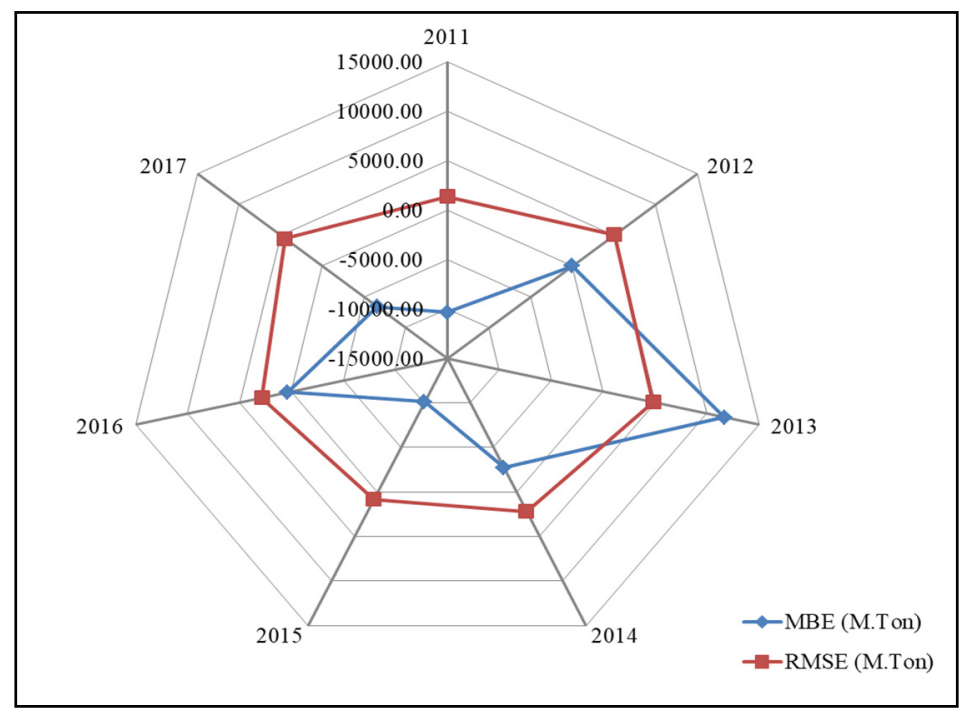

Figure 5. Radar chart shows statistical accuracy of Remote Sensing (RS) model simulation for each year.

However, the inaccuracies in the model can be found due to the presence of cloud [57] and atmospheric-moisture contamination in the NDVI signals, methodological drawbacks and ground data collection procedure, heterogeneous characteristics of fragmented landscapes [51], climatic variability of different meteorological parameters over the season, as well as the frequency of natural disasters [58-60]. Based on the graphic inspection and statistical suitability test i.e., $\mathrm{R}^{2}$, RMSE, and ME of RS modeled and ground-based estimates of BBS it can be inferred that the remote sensing-derived Aman rice-cropped production can be predicted from the MODIS-NDVI based regression model. This proposed model provides a flexible way of generating Aman crop production statistics at the country scale in the heterogeneous landscape of Bangladesh. This model shows promising results in predicting Aman crop production, though there may have some limitations in its present form, but there are ways to improve 
in the future implications. Moreover, the developed satellite remote sensing-based model needs to be assessed before implementing it in other geographical locations.

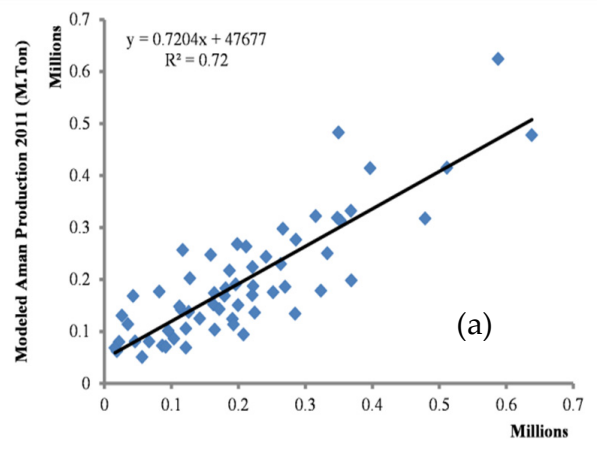

BBS Estimated Aman Production 2011(M.Ton)

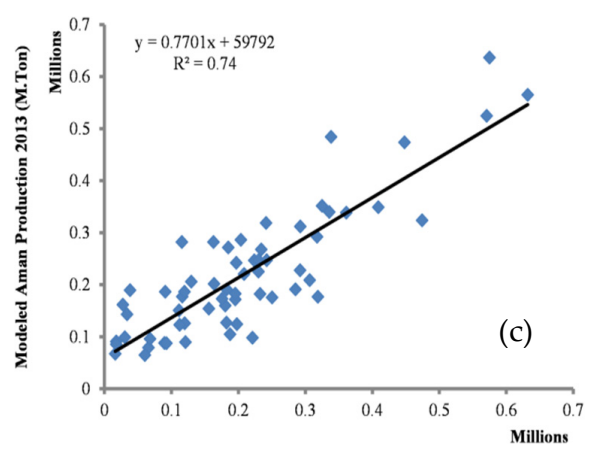

BBS Estimated Aman Production 2013 (M.Ton)

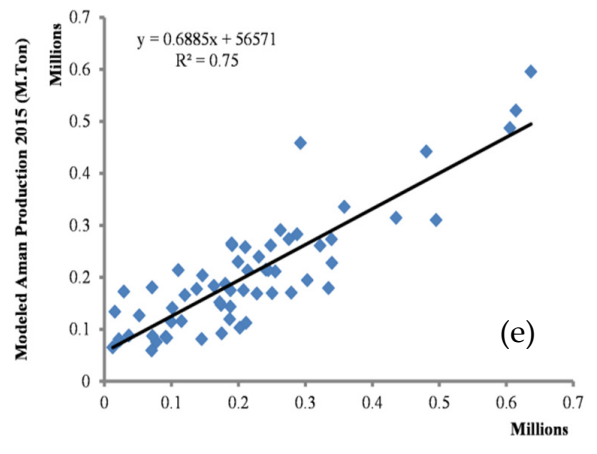

BBS Estimated Aman Production 2015 (M.Ton)

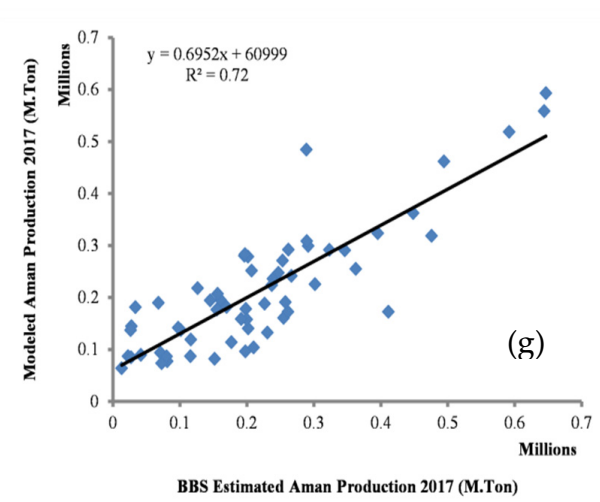

Figure 6. Correlation between RS model-based forecasted and ground-based (BBS estimated) production estimates at 61 district-levels during (a) 2011; (b) 2012; (c) 2013; (d) 2014; (e) 2015; (f) 2016; and, (g) 2017.

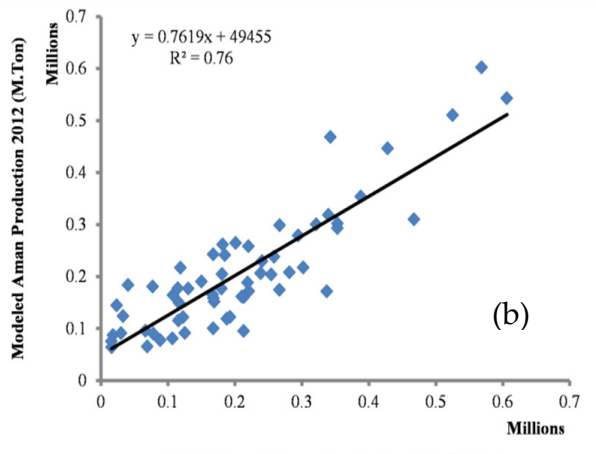

BBS Estimated Aman Production 2012 (M.Ton)

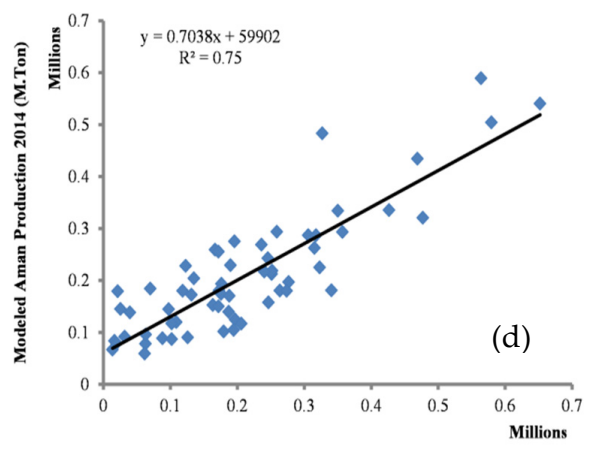

BBS Estimated Aman Production 2014 (M.Ton)

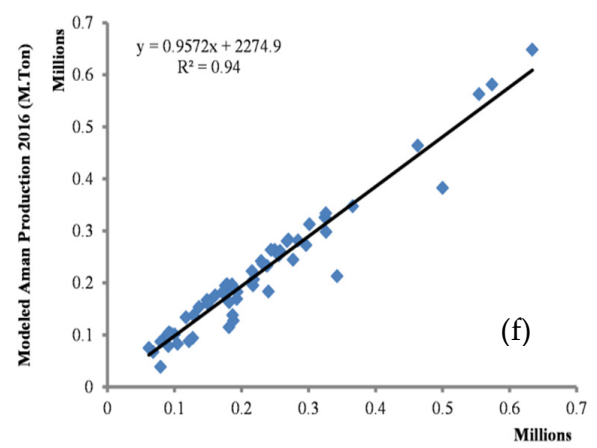

BBS Estimated Aman Production 2016 (M.Ton) 


\section{Conclusions}

The necessity of effective rice crop production estimation in the context of Bangladesh under the consequences of climate change phenomena is well documented. This research work solely looks forward to apply the satellite remote sensing-based Aman crop production forecasting in advance where MODIS-MVC data product MOD13A1 appears to be effective. This methodological framework directly calculates the district-wise rice production statistics based on pixel-by-pixel NDVI summation. A strong correlation is found between the district wise pixel-based summation of MODIS derived NDVI and ground-based BBS estimated Aman production. The time series analysis of NDVI products over the time period 2011-2017 implies that MODIS NDVI and BBS estimated statistics based regression models can estimate and predict the crop production effectively, as the predicted estimation shows resemblance to national crop statistics with reasonable statistical accuracy. Nevertheless, the developed models do not consider the pest invasion. Furthermore, this model needs to be validated from ground-based observation in order to enhance its forecasting ability. Beyond this limitation, the present research findings can add important value to the country's national food security issues.

Author Contributions: All authors contributed systematically to the research work presented in this paper. B.M.R.F. comprehensively processed satellite data, described research findings, and wrote the manuscript. H.R. conceptualized the research theme and provided instruction in all the process of completing the article. N.H.S., N.S., M.I.I., S.M.A.H. and T.A. explore the study outcome and positively modified the manuscript at all stages of preparing the article. All authors have read and agreed to the published version of the manuscript.

Funding: The present research work has no external funding.

Acknowledgments: We would like to thank The National Aeronautics and Space Administration (NASA) for providing the MODIS-derived NDVI data and Bangladesh Bureau of Statistics for providing ground-based estimates to develop model based Aman rice production forecasting estimates. We also want to extend our gratitude to Bangladesh Space Research and Remote Sensing Organization (SPARRSO) for technical assistance and service. Furthermore, this article has been enormously benefited from three anonymous reviewers and editorial office.

Conflicts of Interest: The authors declare no conflict of interest.

\section{Appendix A}

Table A1. Satellite remote sensing based monthly scale regression models for Aman crop production (2011-2017).

\begin{tabular}{ccccccc}
\hline Input Variables & Month & Day & Year & $\begin{array}{c}\text { Satellite-Based Aman Crop } \\
\text { Production Model }\end{array}$ & $\begin{array}{c}\mathbf{R}^{2} \text { : Determination } \\
\text { Coefficient }\end{array}$ \\
\hline MODIS NDVI (MOD13Q1) & Sep & 30 & 2011 & $\mathrm{y}=0.2517$ & $\mathrm{x}=(-23,193)$ & 0.74 \\
Versus Ground-based & Nov & 16 & 2011 & $\mathrm{y}=0.2598$ & $\mathrm{x}=(-18,833)$ & 0.72 \\
Estimated Production of 2011 & Nov & 17 & 2011 & $\mathrm{y}=0.2911$ & $\mathrm{x}=(-24,592)$ & 0.69 \\
& Sep & 29 & 2012 & $\mathrm{y}=0.2596$ & $\mathrm{x}=(-21,026)$ & 0.78 \\
MODIS NDVI (MOD13Q1) & Oct & 15 & 2012 & $\mathrm{y}=0.2605$ & $\mathrm{x}=(-29,779)$ & 0.76 \\
Versus Ground-based & Oct & 31 & 2012 & $\mathrm{y}=0.2776$ & $\mathrm{x}=(-24,748)$ & 0.74 \\
Estimated Production of 2012 & Nov & 16 & 2012 & $\mathrm{y}=0.3118$ & $\mathrm{x}=(-19,556)$ & 0.62 \\
\hline & Sep & 30 & 2013 & $\mathrm{y}=0.2431$ & $\mathrm{x}=(-28,042)$ & 0.74 \\
MODIS NDVI (MOD13Q1) & Oct & 16 & 2013 & $\mathrm{y}=0.2511$ & $\mathrm{x}=(-32,388)$ & 0.74 \\
Versus Ground-based & Nov & 1 & 2013 & $\mathrm{y}=0.3003$ & $\mathrm{x}=(-31,778)$ & 0.73 \\
Estimated Production of 2013 & Nov & 17 & 2013 & $\mathrm{y}=0.3318$ & $\mathrm{x}=(-23,808)$ & 0.63 \\
\hline \multirow{2}{*}{ MODIS NDVI (MOD13Q1) } & Sep & 30 & 2014 & $\mathrm{y}=0.2657$ & $\mathrm{x}=(-38,250)$ & 0.74 \\
Versus Ground-based & Oct & 16 & 2014 & $\mathrm{y}=0.2757$ & $\mathrm{x}=(-41,011)$ & 0.75 \\
Estimated Production of 2014 & Oct & 31 & 2014 & $\mathrm{y}=0.298$ & $\mathrm{x}=(-35,704)$ & 0.68 \\
& Nov & 17 & 2014 & $\mathrm{y}=0.3439$ & $\mathrm{x}=(-14,072)$ & 0.54 \\
\hline
\end{tabular}


Table A1. Cont.

\begin{tabular}{ccccccc}
\hline Input Variables & Month & Day & Year & $\begin{array}{c}\text { Satellite-Based Aman Crop } \\
\text { Production Model }\end{array}$ & $\begin{array}{c}\mathbf{R}^{2} \text { : Determination } \\
\text { Coefficient }\end{array}$ \\
\hline MODIS NDVI (MOD13Q1) & Sep & 30 & 2015 & $\mathrm{y}=0.2622$ & $\mathrm{x}=(-34,210)$ & 0.65 \\
Versus Ground-based & Nov & 16 & 2015 & $\mathrm{y}=0.1754$ & $\mathrm{x}=(-26,854)$ & 0.64 \\
Estimated Production 2015 & Nov & 17 & 2015 & $\mathrm{y}=0.3107$ & $\mathrm{x}=(-35,090)$ & 0.68 \\
& Sep & 29 & 2015 & $\mathrm{y}=0.3157$ & $\mathrm{x}=(-16,129)$ & 0.54 \\
\hline MODIS NDVI (MOD13Q1) & Oct & 16 & 2016 & $\mathrm{y}=0.2562$ & $\mathrm{x}=(-11,222)$ & 0.70 \\
Versus Ground-based & Oct & 31 & 2016 & $\mathrm{y}=0.2601$ & $\mathrm{x}=(-29,813)$ & 0.74 \\
Estimated Production of 2016 & Nov & 17 & 2016 & $\mathrm{y}=0.3352$ & $\mathrm{x}=(-29,783)$ & 0.74 \\
& Sep & 30 & 2017 & $\mathrm{y}=0.2558$ & $\mathrm{x}=(-8147.3)$ & 0.55 \\
MODIS NDVI (MOD13Q1) & Oct & 16 & 2017 & $\mathrm{y}=0.2716$ & $\mathrm{x}=(-33,632)$ & 0.69 \\
Versus Ground-based & Nov & 1 & 2017 & $\mathrm{y}=0.2878$ & $\mathrm{x}=(-31,295)$ & 0.68 \\
Estimated Production of 2017 & Nov & 17 & 2017 & $\mathrm{y}=0.3209$ & $\mathrm{x}=(-20,336)$ & 0.62 \\
\end{tabular}

Table A2. Comparative statistical analysis of RS Model and BBS estimated Aman production (2011-2017).

\begin{tabular}{ccccccc}
\hline \multirow{2}{*}{ Year } & \multicolumn{2}{c}{ Aman Rice Production (M.Ton) } & \multirow{2}{*}{$\mathbf{R}^{\mathbf{2}}$} & \multirow{2}{*}{ MBE (M.Ton) } & \multirow{2}{*}{ RMSE (M.Ton) } & \multirow{2}{*}{ ME } \\
\cline { 2 - 3 } & RS Model Estimated & BBS Estimated & & & & \\
\hline 2011 & $12,029,108$ & $12,660,663$ & 0.72 & $-10,353$ & 1374 & 0.90 \\
2012 & $12,663,105$ & $12,661,584$ & 0.76 & 24 & 5067 & 0.92 \\
2013 & $13,473,504$ & $12,760,304$ & 0.74 & 11,691 & 4831 & 0.92 \\
2014 & $12,729,610$ & $12,895,079$ & 0.75 & -2712 & 2191 & 0.91 \\
2015 & $12,442,664$ & $13,060,239$ & 0.75 & $-10,124$ & 842 & 0.90 \\
2016 & $13,372,820$ & $13,352,668$ & 0.94 & 330 & 2818 & 0.91 \\
2017 & $13,125,570$ & $13,528,734$ & 0.72 & -6609 & 4449 & 0.90 \\
\hline
\end{tabular}

\section{References}

1. Bangladesh Bureau of Statistics (BBS). Yearbook of Agricultural Statistics (2010-2012); Statistics and Informatics Division (SID), Ministry of Planning, Government of the People's Republic of Bangladesh: Dhaka, Bangladesh. Available online: http://www.bbs.gov.bd (accessed on 21 January 2019).

2. Sattar, S.A. Bridging the Rice Yield Gap in Bangladesh. In Bridging the Rice Yield Gap in the Asia-Pacific Region; Papademetriou, M.K., Dent, F.J., Herath, E.M., Eds.; FAO Regional Office of the UN for Asia and the Pacific: Bangkok, Thailand, 2000.

3. Wang, L.-F.; Kong, J.A.; Ding, K.H.; Le Toan, T.; Ribbes, F.; Floury, N. Electromagetic Scattering Model for Rice Canopy B+ased on Monte Carlo Simulation. Progress Electromagn. Res. 2005, 52, 153-171. [CrossRef]

4. Rashid, M.M. Rice Production in Bangladesh: Programmes, Achievements, Potentials and Challenges; International Rice Commission Newsletter, FAO: Rome, Italy, 1994; Volume 43, pp. 9-18.

5. FAO. Rice: Post-harvest Operations; Food and Agriculture Organization (FAO) of United Nations, International Rice Research Institute: Los Baños, Philippines, 1999; Available online: http://www.fao.org/fileadmin/user_ upload/inpho/docs/Post_Harvest_Compendium_-_RICE.pdf (accessed on 21 January 2019).

6. Reynolds, C.A.; Yitayew, M.; Slack, D.C.; Hutchinson, C.F.; Huete, A.; Petersen, M.S. Estimating crop yields and production by integrating the FAO crop specific water balance model with real- time satellite data and ground-based ancillary data. Int. J. Remote Sens. 2000, 21, 3487-3508. [CrossRef]

7. Narasimhan, R.L.; Chandra, H. Application of remote sensing in agricultural statistics. Indian J. Agric. Econ. 2000, 55, 120-124.

8. Dadhwal, V.K.; Ray, S.S. Crop assessment using remote sensing-Part II: Crop condition and yield assessment. Indian J. Agric. Econ. 2000, 55, 54-67.

9. Bastiaanssen, W.G.M.; Ali, S. A new crop yield forecasting model based on satellite measurements applied across the Indus Basin Pakistan. Agric. Ecosyst. Environ. 2003, 94, 321-340. [CrossRef] 
10. Prasad, A.K.; Chai, L.; Singh, R.P. Crop yield estimation model for Iowa using remote sensing and surface parameters. Int. J. Appl. Earth Obs. Geoinf. 2006, 8, 26-33. [CrossRef]

11. Banair, A. A review of vegetation indices. Remote Sens. 1995, 13, 95-120. [CrossRef]

12. Zhao, L.; Duan, L. The analysis of main factors affecting grain yield in Inner Mongolia Autonomous Region. J. Northwest Sci.-Tec. Univ. Agric. Forest. 2001, 29, 77-80.

13. Nuarsa, I.W.; Nishio, F.; Hongo, C. Rice yield estimation using Landsat ETM+ data and field observation. J. Agric. Sci. 2012, 4, 45-56. [CrossRef]

14. Seifried, R. Archaeology in (Geo)Space, Stories from One GIS-Using-Archaeologist to Another. Available online: https://rmseifried.com/2014/09/19/satellite-imagery-types-resolution-and-pricing (accessed on 19 October 2017).

15. Kohiyama, M.; Estrada, M.; Yamazaki, F. Damage Detection Method Using Middle-Resolution Resolution Optical Satellite Images Based on Normal Fluctuation of Digital Numbers in Multi-Temporal Images; Workshop on Application of Remote Sensing Technologies for Disaster Response: Tokyo, Japan, 12 September 2003.

16. Whitcraft, A.K.; Becker-Reshef, I.; Justice, C.O. A framework for defining spatially explicit earth observation requirements for a global agricultural monitoring initiative (GEOGLAM). Remote Sens. 2015, 7, 1461-1481. [CrossRef]

17. Okamoto, K. Estimation of rice-planted area in the tropical zone using a combination of optical and microwave satellite sensor data. Int. J. Remote Sens. 1999, 20, 1045-1048. [CrossRef]

18. Wiegand, C.L.; Rechardson, A.J.; Escobar, D.E.; Gerbermann, A.H. Vegetation indices in crop assessment. Remote Sens. Environ. 1990, 35, 105-119. [CrossRef]

19. Holben, B.N.; Tucker, C.J.; Fan, C.J. Spectral assessment of soybean leaf area and leaf biomass. Photogramm. Eng. Remote Sens. 1980, 46, 651-656.

20. Nemani, R.R.; Running, S.W. Testing a theoretical climate-soil leaf area hydrological equilibrium of forests using satellite data and ecosystem simulation. Agric. For. Meteorol. 1989, 44, 245-260. [CrossRef]

21. Mkhabela, M.S.; Bullock, P.; Raj, S.; Wang, S.; Yang, Y. Crop yield forecasting on the Canadian prairies using MODIS NDVI data. Agric. For. Meteol. 2011, 151, 385-393. [CrossRef]

22. Kouadio, L.; Newlands, N.K.; Davidson, A.; Zhang, Y.; Chipanshi, A. Assessing the Performance of MODIS NDVI and EVI for seasonal crop yield forecasting at the eco district scale. Agric. For. Meteorol. 2014, 173, 74-84.

23. Mahboob, M.G.; Islam, A.T.; Deshapriya, L. Rice mapping and monitoring in Sylhet region of Bangladesh using MODIS NDVI. In Proceedings of the Asia Flux Mini-Workshop on Remote sensing and ecological/environmental monitoring, National Taiwan University, Taipei, Taiwani, 2-4 March 2016; Available online: http://asiaflux.net/index.php?key=muhz8divr-26\#_26 (accessed on 21 January 2019).

24. Faisal, B.; Rahman, H.; Sharifee, N.; Sultana, N.; Islam, M.; Ahammad, T. Remotely Sensed Boro Rice Production Forecasting Using MODIS-NDVI: A Bangladesh Perspective. AgriEngineering 2019, 1, 356-375. [CrossRef]

25. Boschetti, M.; Stroppiana, D.; Brivio, P.A.; Bocchi, S. Multi-year monitoring of rice crop phenology through time series analysis of MODIS images. Int. J. Remote Sens. 2009, 30, 4643-4662. [CrossRef]

26. Colombo, R.; Busetto, L.; Fava, F.; Di Mauro, B.; Migliavacca, M.; Cremonese, E.; Galvagno, M.; Rossini, M.; Meroni, M.; Cogliati, S.; et al. Phenological monitoring of grassland and larch in the Alps from Terra and Aqua MODIS images. Ital. J. Remote Sens. 2011, 43, 83-96.

27. Hmimina, G.; Dufrene, E.; Pontailler, J.Y.; Delpierre, N.; Aubinet, M.; Caquet, B.; de Grandcourt, A.; Burban, B.; Flechar, C.; Granier, A.; et al. Evaluation of the potential ofMODIS satellite data to predict vegetation phenology in different biomes: An investigation using ground-based NDVI measurements. Remote Sens. Environ. 2013, 132, 145-158. [CrossRef]

28. Soudani, K.; Francois, C.; le Maire, G.; Le Dantec, V.; Dufrene, E. Comparative analysis of IKONOS, SPOT, and ETM+ data leaf area index estimation in temperature coniferous and deciduous forest stands. Remote Sens. Environ. 2006, 102, 161-175. [CrossRef]

29. Sesnie, S.E.; Dickson, B.G.; Rosenstock, S.S.; Rundall, J.M. A comparison of Landsat TM and MODIS vegetation indices for estimating forage phenology in desert bighorn sheep (Oviscanadensisnelsoni) habitat in the Sonoran Desert, USA. Int. J. Remote Sens. 2012, 33, 276-286. [CrossRef] 
30. Xiao, X.; Boles, S.; Liu, J.; Zhuang, D.; Frolking, S.; Li, C.; Salas, W.; Moore, B., III. Mapping paddy rice agriculture in southern China using multi-temporal MODIS images. Remote Sens. Environ. 2005, 95, 480-492. [CrossRef]

31. Xiao, X.; Boles, S.; Frolking, S.; Li, C.S.; Babu, J.Y.; Salas, W.; Moore, B., III. Mapping paddy rice agriculture in South and Southeast Asia using multi-temporal MODIS images. Remote Sens. Environ. 2006, 100, $95-113$. [CrossRef]

32. Shiu, Y.; Lin, M.; Huang, C.; Chu, T. Mapping paddy rice agriculture in a highly fragmented area using a geographic information system object-based post classification process. J. Appl. Remote Sens. 2012, 6, 063526.

33. Master Planning Organization (MPO). National Water Management Plan: Phase II; Final Report-1991; Ministry of Irrigation, Water Development and Flood Control, Government of the People's Republic of Bangladesh: Dhaka, Bangladesh, 1991.

34. Gumma, M.K.; Thenkabail, P.S.; Maunahan, A.; Islam, S.; Nelson, A. Mapping seasonal rice cropland extent and area in the high cropping intensity environment of Bangladesh using MODIS 500m data for the year 2010. Isprs J. Photogramm. Remote Sens. 2014, 91, 98-113. [CrossRef]

35. Nelson, A.; Setiyono, T.; Rala, A.; Quicho, E.; Raviz, J.; Abonete, P.; Maunahan, A.; Garcia, C.; Bhatti, H.; Villano, L.; et al. Towards an Operational SAR-Based Rice Monitoring System in Asia: Examples from 13 Demonstration Sites across Asia in the RIICE Project. Remote Sens. 2014, 6, 10773-10812. [CrossRef]

36. Bangladesh Bureau of Statistics (BBS). Statistical Pocketbook of Bangladesh-2016; Government of the People's Republic of Bangladesh: Dhaka, Bangladesh, 2017. Available online: http://www.bbs.gov.bd (accessed on 21 January 2019).

37. Bangladesh Bureau of Statistics (BBS). Statistical Pocketbook of Bangladesh-2006; Government of the People's Republic of Bangladesh: Dhaka, Bangladesh, 2007. Available online: http://www.bbs.gov.bd (accessed on 21 January 2019).

38. Didan, K. MOD13A1: MODIS/Terra Vegetation Indices 16-Day L3 Global 500m SIN Grid V006; NASA EOSDIS LP DAAC: Sioux Falls, SD, USA, 2015.

39. Bangladesh Bureau of Statistics (BBS). Yearbook of Agricultural Statistics-2016; Statistics and Informatics Division (SID), Ministry of Planning, Government of the People's Republic of Bangladesh: Dhaka, Bangladesh, 2017. Available online: http://www.bbs.gov.bd (accessed on 21 January 2019).

40. Bala, S.K.; Islam, A.S. Correlation between potato yield and MODIS-derived vegetation indices. Int. J. Remote Sens. 2009, 30, 2491-2507. [CrossRef]

41. Gat, N.; Erives, H.; Fitzegerald, G.J.; Ka_ka, S.R.; Mass, S.J. Estimate Sugar Beet Yield Using AVIRIS-Derived Indices. 2000. Available online: http://makalu.jpl.nasa.gov/docs/workshops/00_docs/Gat_web.pdf (accessed on 18 September 2007).

42. Liu, W.T.; Kogan, F. Monitoring Brazilian soybean production using NOAA/AVHRR based vegetation condition indices. Int. J. Remote Sens. 2002, 23, 1161-1179. [CrossRef]

43. Nessa, M. Monitoring of Rice Growth and Production in Bangladesh Using NOAA Satellite Data; Bangladesh University of Engineering and Technology: Dhaka, Bangladesh, 2004.

44. Becker-Reshef, I.; Justice, C.; Sullivan, M.; Vermote, E.; Tucker, C.; Anyamba, A.; Small, J.; Pak, E.; Masuoka, E.; Schmaltz, J.; et al. Monitoring global croplands with coarse resolution earth observations: The global agriculture monitoring (GLAM) project. Remote Sens. 2010, 2, 1589-1609. [CrossRef]

45. Boken, V.K.; Shaykewich, C.F. Improving an operational wheat yield model using phenological phase-based Normalized Di_erence Vegetation Index. Int. J. Remote Sens. 2002, 23, 4155-4168. [CrossRef]

46. Rojas, O. Operational maize yield model development and validation based on remote sensing and agro-meteorological data in Kenya. Int. J. Remote Sens. 2007, 28, 3775-3793. [CrossRef]

47. Doraiswamy, P.C.; Cook, P.W. Spring wheat yield assessment using NOAA AVHRR data. Can. J. Remote Sens. 1995, 21, 43-51. [CrossRef]

48. Benedetti, R.; Rossini, P. On the use of NDVI profiles as a tool for agricultural statistics: The case study of wheat yield estimate and forecast in Emilia Romagna. Remote Sens. Environ. 1993, 45, 311-326. [CrossRef]

49. Tucker, C.J.; Holben, B.N.; Elgin, J.H.; McMurtrey, J.E. Relationship of spectral data to grain yield variation. Photogramm. Eng. Remote Sens. 1980, 46, 657-666.

50. Nuarsa, I.W.; Nishio, F.; Hongo, C. Relationship between rice spectral and rice yield using MODIS data. J. Agric. Sci. 2011, 3, 80-88. [CrossRef] 
51. Siyal, A.A.; Dempewolf, J.; Becker-Reshef, I. Rice yield estimation using Landsat ETM_Data. J. Appl. Remote Sens. 2015, 9, 095986. [CrossRef]

52. Huang, J.; Wang, X.; Li, X.; Tian, H.; Pan, Z. Remotely sensed rice yield prediction using multi-temporal NDVI data derived from NOAA's-AVHRR. PLoS ONE 2013, 8, e70816. [CrossRef]

53. Noureldin, N.A.; Aboelghar, M.A.; Saudy, H.S.; Ali, A.M. Rice yield forecasting models using satellite imagery in Egypt. Egypt. J. Remote Sens. Space Sci. 2013, 16, 125-131. [CrossRef]

54. Willmott, C.J. Some comments on the evaluation of model performance. Bull. Am. Meteorol. Soc. 1982, 63, 1309-1313. [CrossRef]

55. Chai, T.; Draxler, R.R. Root mean square error (RMSE) or mean absolute error (MAE)?-Arguments against avoiding RMSE in the literature. Geosci. Model Dev. 2014, 7, 1247-1250. [CrossRef]

56. Fuller, D.O. Trends in NDVI time series and their relation to rangeland and crop production in Senegal, 1987-1993. Int. J. Remote Sens. 1998, 19, 2013-2018. [CrossRef]

57. Shew, A.M.; Ghosh, A. Using multi-temporal remote sensing data to analyze the spatio-temporal patterns of dry season rice production in Bangladesh. In Proceedings of the 2nd International Symposium on Spatiotemporal Computing, ISPRS Annals of the Photogrammetry, Remote Sensing and Spatial Information Sciences, Cambridge, MA, USA, 7-9 August 2017; Volume IV-4/W2.

58. Son, N.T.; Chen, C.F.; Chen, C.R.; Chang, L.Y.; Duc, H.N.; Nguyen, L.D. Prediction of rice crop yield using MODIS EVI-LAI -data in the Mekong Delta, Vietnam. Int. J. Remote Sens. 2013, 34, 7275-7292. [CrossRef]

59. Wang, Y.P.; Chang, K.W.; Chen, R.K.; LO, J.C.; Shen, Y. Large-area rice yield forecasting using satellite imageries. Int. J. Appl. Earth Obs. Geoinf. 2010, 12, 27-35. [CrossRef]

60. Mosleh, M.K.; Hassan, Q.K.; Chowdhury, E.H. Application of remote sensors in mapping rice area and forecasting its production: A review. Sensors 2015, 15, 769-791. [CrossRef]

(C) 2020 by the authors. Licensee MDPI, Basel, Switzerland. This article is an open access article distributed under the terms and conditions of the Creative Commons Attribution (CC BY) license (http://creativecommons.org/licenses/by/4.0/). 